\title{
Assessing cardiovascular risk in ATM heterozygotes
}

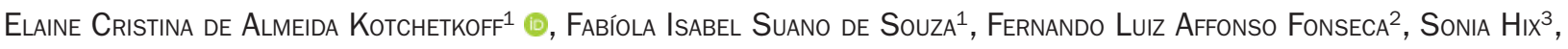 \\ Sergio Aron Ajzen ${ }^{4}$, David Carlos Shigueoka ${ }^{4}$, Beatriz Tavares Costa Carvalho ${ }^{1 *}$, Roseli Oselka Saccardo Sarni ${ }^{1}$ \\ ${ }^{1}$ Pediatrics Department, Escola Paulista de Medicina - Universidade Federal de São Paulo (EPM-Unifesp), São Paulo, SP, Brazil \\ ${ }^{2}$ Assistant Professor, Faculdade de Medicina do ABC (FMABC), Santo André, SP, Brazil; Adjunct Professor IV, Unifesp, Diadema, SP, Brazil \\ ${ }^{3}$ Department of Morphology and Physiology, FMABC, Santo André, SP, Brazil \\ ${ }^{4}$ Department of Diagnostic Imaging, EPM-Unifesp, São Paulo, SP, Brazil
}

Study conducted by Discipline of Allergy, Immunology and Rheumatology, Pediatrics Department, Escola Paulista de Medicina, Universidade Federal de São Paulo (Unifesp), São Paulo, SP, Brazil

Article received: $5 / 26 / 2017$ Accepted for publication: $8 / 6 / 2017$

*Correspondence: Address: Rua dos Otonis, 725 , Vila Clementino

São Paulo, SP - Brasil

Postal code: 04025-002 beacarvalho@terra.com.br

http://dx.doi.org/10.1590/1806-9282.64.02.148

\section{SUMMARY}

Objective: To evaluate the carotid intima-media complex (CIMC) thickness and lipid metabolism biomarkers associated with cardiovascular risk (CR) in parents of patients with ataxia-telangiectasia and verify an association with gender.

Method: A cross-sectional and controlled study with 29 ATM heterozygotes and 14 healthy controls. Biochemical tests and CIMC thickness measurement were performed.

Results: The mean CIMC measurement in heterozygous ATM was $0.72 \pm 0.1 \mathrm{~mm}$ (minimum: $0.5 \mathrm{~mm}$ and maximum: $1.0 \mathrm{~mm}$ ). Noticed high percentage of amounts above 75 percentile compared to the population referential (16 [76.2\%]), without any significant statistical differences between the female and the male gender $(11 / 15$ [73.3\%] vs. $5 / 6$ [83.3\%]; $\mathrm{p}=0.550)$. The comparison between heterozygous and controls, stratified by gender, showed that in heterozygous ATMs, women had higher concentrations of HDL-c compared to men, as well as higher values of hs-CRP in relation to the control women. In heterozygous ATMs, stratified by gender, the correlation between HDL-c and hs-CRP was inversely proportional and stronger among women, with a tendency to statistical significance.

Conclusion: Heterozygous ATMs did not differ from controls in relation to the biomarkers studied related to CR. However, most of them presented increased CIMC, independent predictor of death, risk for myocardial infarction and stroke, compared to the referential for the same age group. This finding suggests $\mathrm{CR}$ in the heterozygous ATM and shows to the need to monitor CIMC thickness and nutritional orientations.

Keywords: Ataxia Telangiectasia. Atherosclerosis. Carotid Intima-Media Thickness. Insulin Resistance. Heterozygote.

\section{INTRODUCTION}

Ataxia-telangiectasia (A-T) is a rare autosomal recessive syndrome that affects 1:40,000 live births in the United States. ${ }^{1}$ The classic symptoms, which gave rise to the name for the disorder, are ataxia (loss of motor coordination onset in early childhood) and telangiectasias (venous capillaries dilated in the corners of the eyes and skin, occurring around 4-6 years of age). ${ }^{2}$

Caused by mutations of the ATM gene (ataxia telangiectasia mutated) ${ }^{3,4}$ which is encoded on chromosome $11 \mathrm{q} 22-23$, the protein associated with this gene is com- posed of 3,056 amino acids, belongs to the PIKK (phosphatidylinositol 3-kinase-related kinases) superfamily, ${ }^{4}$ and is involved in DNA damage-response regulation., ${ }^{2,5}$

The ATM protein follows several molecular events. Its absence or failure induces the collapse of several mechanisms related to the development of disorders, including cardiovascular $(\mathrm{CV})$ diseases. These mechanisms are described in the literature by means of experimental studies ${ }^{6-14}$ and, more recently, by virtue of increased patient survival in studies with humans. ${ }^{15}$ The mechanisms involved in $\mathrm{CV}$ risk associated with ATM failure entail increased c-jun 
$\mathrm{N}$-terminal kinase (JNK, related to metabolic syndrome), insulin resistance, dyslipidemia, angiogenesis, myocyte apoptosis and oxidative stress. ${ }^{6,8-13,16}$

ATM heterozygotes, who carry a mutant allele to the A-T locus, account for from 1.4 to $2 \%$ of the population. ${ }^{1,17}$ A systematic review and a recent meta-analysis showed that first-degree relatives, parents and grandparents of A-T patients have an increased risk of ischemic heart disease. ${ }^{18}$

A retrospective controlled cohort study was conducted over 28 years with grandparents of A-T patients, i.e. individuals having the mutation, with the purpose of describing mortality rates. A total of 405 grandparents (204 ATM heterozygotes, as assessed by genotyping, and 201 controls) were included. Compared to controls, ATM heterozygotes had a significantly higher risk of death (between 20 and 79 years RR 1.9, 95CI 1.3-2.8, $\mathrm{p}<0.001)$. On average, death occurred 7 to 8 years earlier among ATM heterozygotes. The relative risk of death from cancer and ischemic heart disease before age 80 was 2.6 (95CI 1.4-4.7, $\mathrm{p}=0.002$ ) and 2.0 (95CI 1-4, $\mathrm{p}=0.062$ ), respectively. With respect to ischemic heart disease, death among ATM heterozygotes occurred 11 years earlier than in the control group ( $\mathrm{p}=0.006)$, which was not observed for cancer. ${ }^{19}$

Studies describing CV risk mechanisms in A-T carriers ${ }^{20}$ and ATM heterozygotes, ${ }^{8,12,13,15}$ conducted either in humans or involving animal experimentation - as well as the scarcity of studies identifying such risk by biochemical and imaging techniques - highlight the need to expand research in this field. The aim of our study was to describe the carotid intima-media complex (CIMC) thickness and lipid metabolism biomarkers associated with $\mathrm{CV}$ risk and then to check whether there is an association with gender.

\section{Method}

A prospective, controlled cross-sectional study evaluated 29 fathers and mothers of patients clinically diagnosed with A-T (herein referred to as ATM heterozygotes). The control group consisted of 14 age/sex-matched healthy volunteers.

The inclusion criteria for the parents were: having offspring diagnosed with A-T in accordance with the PAGID-ESID criteria ${ }^{21,22}$ and consenting to participate in the study. The inclusion criteria for the control group were: consenting to participate in the study, being eutrophic and a non-smoker. The exclusion criterion for both groups was not meeting the abovementioned inclusion criteria.

The study was approved by the Research Ethics Committee of UNIFESP-EPM (No. 921407/2014), and all participants signed a free informed consent form.

Demographic and clinical data were collected by means of a standardized questionnaire. The level of physical activity was assessed by a short version of the International Physical Activity Questionnarie (IPAQ). The individual CV risk was assessed based on the Framingham score. ${ }^{23}$

The anthropometric evaluation was based on weight, height, skin folds (tricipital, subscapular, bicipital, and supra-iliac skin folds), and circumferences (neck, abdominal, and brachial). Neck circumference (NC) measurements were taken and classified according to Ben-Noun et al. ${ }^{24,25}$ The waist-to-height ratio (WhR) was used as a marker of risk for coronary disease. ${ }^{26}$ Food consumption was obtained with the aid of a 24-hour food recall (R24hs). ${ }^{27}$

The following biochemical markers were used: total cholesterol and fractions, triglycerides, fasting glycemia, AST, ALT, GGT, us-CRP, IL-6, PON1, Apo A-I and Apo B. The TC/HDL-c, LDL-c/HDL-c, and Apo B/Apo A-I ratios were calculated. ${ }^{28,29}$

A single examiner took all CIMC thickness measurements, and only from ATM heterozygotes. We used a Medison Accuvix V10 unit with a high-frequency linear transducer $(6-12 \mathrm{MHz})$ and adjusted its focal area to the area of interest (posterior wall of the common carotid artery) and its gain so as to avoid artifacts inside the vessel and yield a $4 x$ magnification. The cutoff point we adopted for percentile classification was an adapted table from the CAPS Study, by age group and gender. ${ }^{30}$

We then entered and consolidated the data in Excel® Office spreadsheets. For the analysis, we used the SPSS $24.0\left(\mathrm{IBM}{ }^{\circledR}\right)$ statistical package. Categorical variables were presented as total numbers (\%) and compared using the Chi-squared test or Fisher's exact test. Continuous variables were tested for their normality. Parameters were presented as mean \pm standard deviation and non-parametric as median (interquartile range). Because they are not parametric, triglycerides, interleukin- 6 and Apo-B values were submitted to the logarithmic transformation for analysis. For bivariate comparison, we used Student's t-test and ANOVA for two or more stations, respectively. In order to evaluate the association between us-CRP and HDL-c, we used Pearson's correlation. For multivariate analysis involving BMI, us-CRP and gender, in turn, we used logistic binary regression, enter method. We adopted a significance level of $5 \%$.

\section{RESULTS}

The general traits found in the ATM heterozygote and control groups can be seen in Table 1. We can observe that there was no difference between the groups in terms of age ( $41.0 \pm 9.3$ years versus $43.3 \pm 8.9$ years, $p=0.420$ ), gender and years of formal education (Table 1 ). 
No serious CV events, such as acute myocardial infarction or stroke in the family, were reported in either group. Other previous conditions preceding CVDs (dyslipidemia, obesity, HBP and diabetes) were cited by $16(55 \%)$ and eight $(57.1 \%)$ participants in the ATM heterozygote and control groups $(\mathrm{p}=0.583)$, respectively (Table 1$)$. The smoking frequency and level of physical activity were similar between both groups (Table 1). Only two women in each group reported having reached menopause.

Dietary intake did not differ between groups for any of the items evaluated: total energy $(2,031.0 \pm 718.6 \mathrm{kcal}$ versus $2,210.5 \pm 627.2 \mathrm{kcal}, \mathrm{p}=0.449)$, protein $\%(15.9 \pm 3.9$ versus $17.3 \pm 3.4, \mathrm{p}=0.180)$, carbohydrate $\%(45.9 \pm 11.0$ versus $44.9 \pm 8.4, \mathrm{p}=0.787)$, fiber $(20.5 \pm 10.5 \mathrm{~g}$ versus $24.1 \pm 17.2 \mathrm{~g}$, $\mathrm{p}=0.680)$, cholesterol $(296.8 \pm 55.8$ versus $316.3 \pm 40.1 \mathrm{mg}$, $\mathrm{p}=0.320)$, total fat $\%(31.8 \pm 9.0$ versus $37.7 \pm 7.8, \mathrm{p}=0.245)$, saturated fat $\%(4.5 \pm 0.7$ versus $4.7 \pm 0.9, \mathrm{p}=0.418)$, mono- unsaturated fat $\%(2.3 \pm 0.4$ versus $2.1 \pm 0.5, \mathrm{p}=0.796)$ or polyunsaturated fat $\%(2.0 \pm 0.3$ versus $2.8 \pm 0.9, \mathrm{p}=0.329)$.

Mean CIMC measure in the ATM heterozygote group was $0.72 \pm 0.1 \mathrm{~mm}$ (minimum: $0.5 \mathrm{~mm}$ and maximum: $1.0 \mathrm{~mm}$ ). We found a high percentage of values above the $75^{\text {th }}$ percentile in comparison to the population reference (16 [76.2\%]), with no statistically significant difference between females and males $(11 / 15$ [73.3\%] versus 5/6 [83.3\%]; $\mathrm{p}=0.550$ ).

We found no difference between the ATM heterozygote and the controls while comparing the variables in a categorized manner with respect to nutritional status and body composition (Table 1). With regard to CVD risk factors, only HBP showed a trend to be more frequent in the ATM heterozygote group (62.0\% versus $28.6 \%, \mathrm{p}=0.055)$. We observed no differences regarding changes in lipid profile, fasting glycemia and MetS (Table 1).

\section{TABLE 1 General characteristics of ATM heterozygotes and controls.}

\begin{tabular}{|c|c|c|c|c|}
\hline Variable & & $\begin{array}{l}\text { ATM H group } \\
(n=29)\end{array}$ & $\begin{array}{l}\text { Control group } \\
(n=14)\end{array}$ & $\mathrm{p}$-value \\
\hline Sex & Female & $21(72.4 \%)$ & $9(64.3 \%)$ & 0.726 \\
\hline Education & $>4$ years & $22(24.1 \%)$ & $12(14.3 \%)$ & 0.693 \\
\hline Family history & CVD & $16(55.2 \%)$ & $8(57.1 \%)$ & 0.583 \\
\hline Use of oral contraceptives & & $4(19.9 \%)$ & $4(44.4 \%)$ & 0.195 \\
\hline Use of alcohol & Social & $17(70.8 \%)$ & $7(29.2 \%)$ & 0.745 \\
\hline Smoking habit & Yes & $3(10.3 \%)$ & $0(0.0 \%)$ & 0.539 \\
\hline \multirow[t]{5}{*}{ Physical activity } & Very active & $8(27.6 \%)$ & $4(28.6 \%)$ & 0.615 \\
\hline & Active & $15(51.7 \%)$ & $7(50.0 \%)$ & \\
\hline & Irregularly active A & $3(10.3 \%)$ & $1(7.1 \%)$ & \\
\hline & Irregularly active B & $1(3.4 \%)$ & $2(15.3 \%)$ & \\
\hline & Sedentary & $2(6.9 \%)$ & $0(0.0 \%)$ & \\
\hline BMI & $>30 \mathrm{~kg} / \mathrm{m}^{2}$ & $5(17.2 \%)$ & $0(0.0 \%)$ & 0.156 \\
\hline Abdominal circumference & $>0.5 \mathrm{~cm} / \mathrm{cm}$ & $19(65.6 \%)$ & $5(35.7 \%)$ & 0.102 \\
\hline Fat percentage & High & $23(79.3 \%)$ & $10(71.4 \%)$ & 0.704 \\
\hline Neck circumference & High & $10(34.5 \%)$ & $1(7.1 \%)$ & 0.071 \\
\hline Blood pressure & High & $18(62.1 \%)$ & $4(28.6 \%)$ & 0.055 \\
\hline Total cholesterol & Inadequate & $15(51.7 \%)$ & $6(42.9 \%)$ & 0.747 \\
\hline LDL-c & Inadequate & $13(44.8 \%)$ & $5(35.7 \%)$ & 0.744 \\
\hline HDL-c & Low & $4(13.8 \%)$ & $2(14.3 \%)$ & 0.649 \\
\hline Triglycerides & Inadequate & $1(3.6 \%)$ & $2(14.3 \%)$ & 0.254 \\
\hline Non HDL-c & Inadequate & $11(37.9 \%)$ & $3(21.4 \%)$ & 0.324 \\
\hline Apolipoprotein B & Inadequate & $17(60.7 \%)$ & $12(85.7 \%)$ & 0.159 \\
\hline Fasting blood glucose & $>100 \mathrm{mg} / \mathrm{dL}$ & $3(10.7 \%)$ & $1(7.1 \%)$ & 0.593 \\
\hline us-CRP & Increased & $9(32.1 \%)$ & $1(7.1 \%)$ & 0.125 \\
\hline Metabolic syndrome & Yes & $3(10.7 \%)$ & $1(7.1 \%)$ & 0.607 \\
\hline
\end{tabular}

Level of significance of the Chi-square test or Fisher's exact test $(p<0.05)$.

CVD: cardiovascular disease; BMI: body mass index; LDL-c: low-density lipoprotein cholesterol; HDL-c: high-density lipoprotein cholesterol; us-CRP: ultra-sensitive C-reactive protein. 
Laboratory test results and anthropometric variables referring to bodily condition were also compared in a continuous fashion between groups. In the bivariate analysis, we found us-CRP to be higher in the ATM heterozygote group $(2.24 \pm 2.30$ versus $1.11 \pm 0.97 \mathrm{mg} / \mathrm{dL}, \mathrm{p}=0.015)$. However, this difference did not hold in the multivariate analysis when we adjusted us-CRP values for BMI and gender $(\mathrm{OR}=1.646,95 \mathrm{CI} 0.75-3.62, \mathrm{p}=0.214)($ Table 2$)$.

A comparison between both groups, stratified by gender, showed that females in the ATM heterozygote group had higher concentrations of HDL-c compared to men in the same group and higher values of us-CRP in women in the control group. The other laboratory variables and BMI did not show a statistically significant difference relative to gender.

In the ATM heterozygote group, stratified by gender, the correlation between HDL-c and us-CRP was inversely proportional and stronger among women, with a tendency to statistical significance $(r=-0.318 ; p=0.083)($ Chart 1$)$.

TABLE 2 Odds ratio of ultra-sensitive C-reactive protein in the ATM heterozygote group adjusted for body mass index and gender.

\begin{tabular}{lllll} 
Variable & B & $\beta$ & $\mathbf{9 5 C l}$ & p-value \\
\hline us-CRP $(\mathrm{mg} / \mathrm{dL})$ & 0.499 & 1.646 & $0.75-3.62$ & 0.214 \\
\hline BMI $\left(\mathrm{kg} / \mathrm{m}^{2}\right)$ & 0.459 & 1.583 & $1.11-2.25$ & 0.011 \\
\hline Gender $($ female $)$ & 1.048 & 2.851 & $0.44-17.45$ & 0.285 \\
\hline Age (years) & 0.004 & 1.004 & $0.91-1.10$ & 0.934 \\
\hline
\end{tabular}

Variables in the model: BMI $\left(\mathrm{kg} / \mathrm{m}^{2}\right)$, age (years) and gender $(\mathrm{p}<0.05)$ us-CRP: ultra-sensitive C-reactive protein.

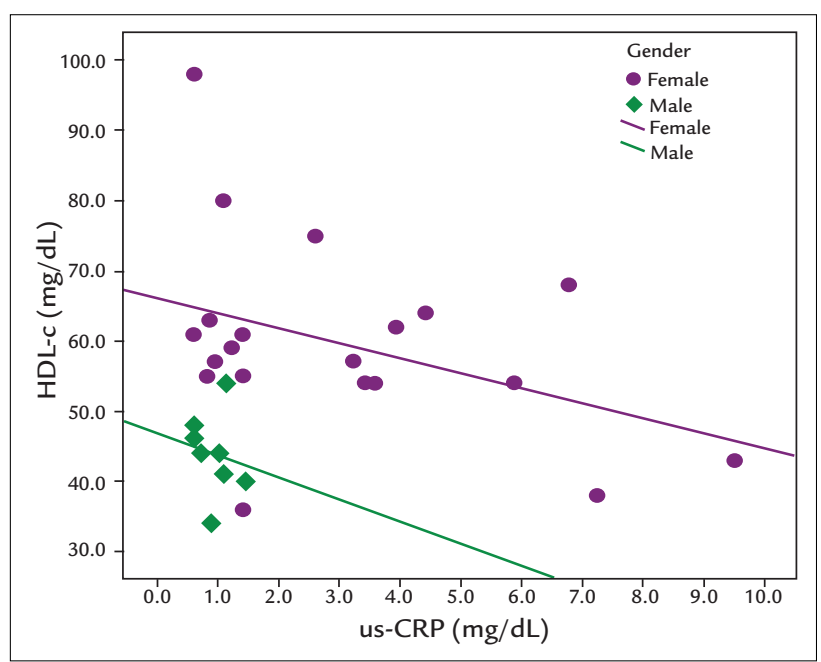

CHART 1 Correlation of HDL-c and us-CRP in the heterozygous ATM group by gender.

*Pearson's correlation (HDL-c and us-CRP)

Females $(r=-0.397 ; p=0.083)$

Males $(r=-0.160 ; p=0.704)$

\section{Discussion}

Our study was pioneer in analyzing $\mathrm{CV}$ risk based on the increase in CIMC thickness in heterozygous carriers of the ATM mutation. Specifically in females, there was also an increase in us-CRP compared to females in the control group. HDL-c concentrations were higher in females as compared to males.

A greater CIMC thickening was observed for both genders and was mostly classified as equal to or above the $75^{\text {th }}$ percentile according to the reference value proposed by Lorenz et al. This indicates the existence of subclinical carotid atherosclerosis in this population. ${ }^{30} \mathrm{~A}$ meta-analysis encompassing 15 studies showed that a $0.1-\mathrm{mm}$ increase in CIMC was predictive of myocardial infarction (RR 1.15, 95CI 1.121.17) and stroke (RR 1.17, 95CI 1.16-1.21). A cohort of eight population-based studies $(n=37,197)$ with a follow-up of approximately five years demonstrated that a difference of only $0.1 \mathrm{~mm}$ in CIMC could increase the risk of myocardial infarction by $10 \%$ to $15 \%$ and stroke by $13 \%$ to $18 \% .{ }^{31} \mathrm{~A}$ study involving 3,067 participants from six cohorts showed that the increase in CIMC was positively associated with the risk of first infarction or stroke in individuals younger than 45 years, thus validating the use of this measurement in identifying risk, even in individuals whose age was similar to that which we studied. ${ }^{32} \mathrm{~A}$ recent review article emphasizes the importance of the CIMC ultrasound evaluation procedure in identifying risk and as a means for predicting CV events. ${ }^{33}$

Some authors suggest that patients with the ATM mutation are at a high risk of diseases such as neoplasms and acute myocardial infarction. ${ }^{19,34-37}$ A systematic review and recent meta-analysis concluded that there is no need to screen heterozygous carriers of the ATM mutation any differently than the general population for assessing $\mathrm{CV}$ risk. Still, it proposes that counseling towards healthy eating habits and lifestyle should be reinforced in that group. ${ }^{18}$ The first publication addressing mortality from ischemic heart diseases in ATM heterozygotes dates from 1983. ${ }^{38}$ Subsequently, other studies suggested a higher susceptibility to coronary atherosclerosis, MS and hypercholesterolemia. ${ }^{8,12}$ Reduced MIRNI25B concentrations found in ATM heterozygotes resulting in overexpression of the CV susceptibility TNFS4 gene might be a possible causal explanation for this association. ${ }^{15}$ In addition, studies with experimental animals have shown that ATM deficiency induces structural and functional changes following myocardial infarction, suggesting problems in remodeling, inflammation and apoptosis following ischemic events. ${ }^{13}$

A study conducted with grandparents of A-T patients undergoing genotyping in order to investigate the mutation showed an increase in the risk of death compared to 
individuals from the same family not carrying the mutation. Compared to non-carriers, death from ischemic heart disease occurred 11 years earlier in carriers. ${ }^{19}$

The heterozygous ATM females in our study had higher us-CRP concentrations compared to the controls. Neutrophils isolated from A-T patients produce a greater amount of proinflammatory cytokines, which is an effect that can be partially explained by the increase in activation in p38MAP kinase. ${ }^{39}$

The association between increased CIMC and lower HDL-c concentrations suggests an even higher CV risk in male ATM heterozygotes. An observational cohort study (CANHEART - Cardiovascular Health in Ambulatory Care Research Team) of 631,762 Canadian individuals, mean age 57.2 years, reported that low HDL-c concentrations were associated with the risk of death from CVD in an independent fashion when compared to individuals with adequate HDL-c levels. ${ }^{40} \mathrm{HDL}-\mathrm{c}$ can be converted from an anti-inflammatory particle to a pro-inflammatory particle in acute-phase situations of the inflammatory response. In this situation, HDL-c loses its antiatherogenic properties, becoming dysfunctional. Proinflammatory HDL particles are characterized by altered protein composition, namely increased levels of ceruloplasmin and serum amyloid A and reduced levels of Apo AI, paraoxonase and acetyl hydrolase PAF-AH (plasma platelet activating factor-acetylhydrolase). ${ }^{41}$ Oxidative stress and inflammation (mechanisms accompanying ATM failure or absence) may contribute to the presence of dysfunctional HDL in ATM heterozygotes.

A study conducted with $13 \mathrm{~A}-\mathrm{T}$ patients, offspring of the ATM heterozygotes assessed in our study, showed that triglycerides, total cholesterol and LDL-c and HDL-c concentrations were significantly higher in patients - and HDL-c concentrations were lower - when compared to healthy controls. The ratios associated with atherosclerosis (TC/HDL-c, LDL-c/HDL-c and Log TG/HDL-c) and non-HDL cholesterol (N-HDL-c) levels were also significantly higher in the group of patients. ${ }^{42}$ There are no studies assessing the concordance between the changes in the lipid profile of patients and their parents, heterozygous carriers of the ATM mutation.

Studies in the literature suggest that healthy eating habits and an appropriate lifestyle should be reinforced among ATM heterozygotes. ${ }^{18}$ In practice, this does not appear to be the case with these individuals, considering that we observed that their food consumption was similar to those in the control group. We found obesity in $17 \%$ of participants, increased abdominal circumference in $65.6 \%$, metabolic syndrome in $11 \%$ and increased CIMC thickness, which is an early marker of atherosclerosis, in $76 \%$ of them. These findings indicate the need to effectively implement such counseling in the routine care given to those families.

Our study had some shortcomings: lack of genotyping for the ATM mutation, a transversal design, and lack of investigation of other biomarkers related to CV risk, such as lipoprotein a (Lpa), LCAT (lecithin cholesterol acetyltransferase) and adhesion molecules, i.e. ICAMs (intercellular adhesion molecules) and VCAM-1 (vascular cell adhesion molecule-1).

\section{Conclusion}

ATM heterozygotes did not differ from control individuals relative to the $\mathrm{CV}$ risk-related biomarkers that we studied. However, most of them had increased CIMC thickness, which is an independent predictor of death, risk of myocardial infarction and stroke, in comparison to reference values for the same age group. This finding suggests a CV risk in ATM heterozygotes and indicates the need for monitoring CIMC thickness, reinforcing nutritional counseling, and stimulating the practice of physical activity.

\section{Resumo}

Avaliação do risco cardiovascular de ATM heterozigotos

Objetivo: Avaliar a espessura do complexo médio-intimal da carótida (CMIC) e os biomarcadores do metabolismo lipídico associados ao risco cardiovascular (RC) em pais de pacientes com ataxia-telangiectasia (AT) e verificar associação com gênero.

Método: Estudo transversal prospectivo e controlado com 29 ATM heterozigotos e 14 controles saudáveis. Foram realizados exames bioquímicos e a espessura do CMIC por ultrassonografia.

Resultados: A média da medida do CMIC nos ATM heterozigotos foi de $0,72 \pm 0,1 \mathrm{~mm}$ (mínimo: $0,5 \mathrm{~mm}$ e máximo: $1,0 \mathrm{~mm}$ ). Observou-se elevado percentual de valores acima do percentil 75 em relação ao referencial populacional $(16$ [76,2\%]), sem diferença estatisticamente significante entre o gênero feminino e o masculino (11/15 $[73,3 \%]$ vs. 5/6 [83,3\%]; $p=0.550)$. A comparação entre os ATM heterozigotos e os controles, estratificados por gênero, mostrou que, nos ATM heterozigotos, as mulheres tinham maiores concentrações de HDL-c em comparação aos homens, e valores mais elevados de PCR-us em relação às mulheres controle. Nos ATM heterozigotos, estratificando segundo gênero, a correlação entre HDL-c e PCR-us foi inversamente proporcional e mais forte entre as mulheres, com tendência à significância estatística. 
Conclusão: Os ATM heterozigotos não diferiram dos controles em relação aos biomarcadores estudados relacionados ao RC. Entretanto, a maioria deles apresentou aumento na espessura do CMIC, preditor independente de morte, risco para infarto do miocárdio e AVC, quando comparado ao referencial para a mesma faixa etária. Esse achado sugere RC nos ATM heterozigotos e aponta para a necessidade de monitoramento da espessura do CMIC e de orientações nutricionais.

Palavras-chave: Ataxia Telangiectasia. Aterosclerose. Espessura Íntima-Média Carotídea. Resistência à Insulina. Heterozigoto.

\section{References}

1. Swift M, Morrell D, Cromartie E, Chamberlin AR, Skolnick MH, Bishop DT. The incidence and gene frequency of ataxia-telangiectasia in the United States. Am J Hum Genet. 1986; 39(5):573-83.

2. Perlman SL, Boder Deceased E, Sedgewick RP, Gatti RA. Ataxia-telangiectasia. Handb Clin Neurol. 2012; 103:307-32.

3. Gatti RA, Berkel I, Boder E, Braedt G, Charmley P, Concannon P, et al. Localization of an ataxia-telangiectasia gene to chromosome 11q22-23. Nature. 1988; 336(6199):577-80.

4. Savitsky K, Bar-Shira A, Gilad S, Rotman G, Ziv Y, Vanagaite L, et al. A single ataxia telangiectasia gene with a product similar to PI-3 kinase. Science. 1995; 268(5218):1749-53

5. Pandita TK. 14th International Workshop on Ataxia-Telangiectasia ATW2012. DNA Repair (Amst). 2012; 11(10):853-6

6. Schofield CJ, Ratcliffe PJ. Oxygen sensing by HIF hydroxylases. Nat Rev Mol Cell Biol. 2004; 5(5):343-54

7. Khurana R, Simons M, Martin JF, Zachary IC. Role of angiogenesis in cardiovascular disease: a critical appraisal. Circulation. 2005; 112(12):1813-24.

8. Wu D, Yang H, Xiang W, Zhou L, Shi M, Julies G, et al. Heterozygous mutation of ataxia-telangiectasia mutated gene aggravates hypercholesterolemia in apoE-deficient mice. J Lipid Res. 2005; 46(7):1380-7.

9. Schneider JG, Finck BN, Ren J, Standley KN, Takagi M, Maclean KH, et al. ATM-dependent suppression of stress signaling reduces vascular disease in metabolic syndrome. Cell Metab. 2006; 4(5):377-89.

10. Foster CR, Singh M, Subramanian V, Singh K. Ataxia telangiectasia mutated kinase plays a protective role in $\beta$-adrenergic receptor-stimulated cardiac myocyte apoptosis and myocardial remodeling. Mol Cell Biochem. 2011; 353(1-2):13-22.

11. Foster CR, Zha Q, Daniel LL, Singh M, Singh K. Lack of ataxia telangiectasia mutated kinase induces structural and functional changes in the heart: role in $\beta$-adrenergic receptor-stimulated apoptosis. Exp Physiol. 2012; 97(4):506-15

12. Mercer JR, Yu E, Figg N, Cheng KK, Prime TA, Griffin JL, et al. The mitochondriatargeted antioxidant MitoQ decreases features of the metabolic syndrome in ATM+/-/ApoE-/- mice. Free Radic Biol Med. 2012; 52(5):841-9.

13. Foster CR, Daniel LL, Daniels CR, Dalal S, Singh M, Singh K. Deficiency of ataxia telangiectasia mutated kinase modulates cardiac remodeling following myocardial infarction: involvement in fibrosis and apoptosis. PLoS One. 2013; 8(12):e83513

14. Kim YW, Byzova TV. Oxidative stress in angiogenesis and vascular disease. Blood. 2014; 123(5):625-31

15. Smirnov DA, Cheung VG. ATM gene mutations result in both recessive and dominant expression phenotypes of genes and microRNAs. Am J Hum Genet. 2008; 83(2):243-53

16. Viniegra JG, Martínez N, Modirassari P, Hernández Losa J, Parada Cobo C, Sánchez-Arévalo VJ, et al. Full activation of PKB/Akt in response to insulin or ionizing radiation is mediated through ATM. J Biol Chem. 2005; 280(6):4029-36.

17. FitzGerald MG, Bean JM, Hegde SR, Unsal H, MacDonald DJ, Harkin DP, et al. Heterozygous ATM mutations do not contribute to early onset of breast cancer. Nat Genet. 1997; 15(3):307-10.
18. van Os NJ, Roeleveld N, Weemaes CM, Jongmans MC, Janssens GO, Taylor AM, et al. Health risks for ataxia-telangiectasia mutated heterozygotes: a systematic review, meta-analysis and evidence-based guideline. Clin Genet. 2016; 90(2):105-17.

19. Su Y, Swift M. Mortality rates among carriers of ataxia-telangiectasia mutant alleles. Ann Intern Med. 2000; 133(10):770-8.

20. Espach Y, Lochner A, Strijdom H, Huisamen B. ATM protein kinase signaling, type 2 diabetes and cardiovascular disease. Cardiovasc Drugs Ther. 2015; 29(1):51-8.

21. Conley ME, Notarangelo LD, Etzioni A. Diagnostic criteria for primary immunodeficiencies. Representing PAGID (Pan-American Group for Immunodeficiency) and ESID (European Society for Immunodeficiencies) Clin Immunol. 1999; 93(3):190-7.

22. European Society for Immunodeficiencies. Diagnostic criteria for primary immunodeficiencies [cited 2016 Jun 22]. Available from: http://www.esid.org.

23. LIoyd-Jones DM, Wilson PW, Larson MG, Beiser A, Leip EP, D'Agostino RB et al. Framingham risk score and prediction of lifetime risk for coronary heart disease. Am J Cardiol. 2004; 94(1):20-4.

24. Ben-Noun L, Sohar E, Laor A. Neck circumference as a simple screening measure for identifying overweight and obese patients. Obes Res. 2001; 9(8):470-7.

25. Ben-Noun L, Laor A. Relationship of neck circumference to cardiovascular risk factors. Obes Res. 2003; 11(2):226-31.

26. Pitanga FJG, Lessa I. Razão cintura-estatura como discriminador do risco coronariano de adultos. Rev Assoc Med Bras. 2006; 52(3):157-61.

27. Buzzard M. 24-hours dietary recall and food record methods. In: Willett WC, editor. Nutritional epidemiology. 2. ed. Oxford: Oxford University Press; 1998. p. 50-73

28. Millán J, Pintó X, Muñoz A, Zúñiga M, Rubiés-Prat J, Pallardo LF, et al. Lipoprotein ratios: physiological significance and clinical usefulness in cardiovascular prevention. Vasc Health Risk Manag. 2009; 5:757-65.

29. Walldius G, Jungner I. The apoB/apoA-I ratio: a strong, new risk factor for cardiovascular disease and a target for lipid-lowering therapy - a review of the evidence. J Intern Med. 2006; 259(5):493-519.

30. Lorenz MW, von Kegler S, Steinmetz H, Markus HS, Sitzer M. Carotid intima-media thickening indicates a higher vascular risk across a wide age range: prospective data from the Carotid Atherosclerosis Progression Study (CAPS). Stroke. 2006; 37(1):87-92

31. Lorenz MW, Markus HS, Bots ML, Rosvall M, Sitzer M. Prediction of clinical cardiovascular events with carotid intima-media thickness: a systematic review and meta-analysis. Circulation. 2007; 115(4):459-67.

32. Eikendal AL, Groenewegen KA, Anderson TJ, Britton AR, Engström G, Evans GW, et al.; USE-IMT Project Group. Common carotid intima-media thickness relates to cardiovascular events in adults aged < 45 years. Hypertension. 2015; 65(4):707-13

33. Polak JF, O'Leary DH. Carotid intima-media thickness as surrogate for and predictor of CVD. Glob Heart. 2016; 11(3):295-312.

34. Pippard EC, Hall AJ, Barker DJ, Bridges BA. Cancer in homozygotes and heterozygotes of ataxia-telangiectasia and xeroderma pigmentosum in Britain. Cancer Res. 1988; 48(10):2929-32.

35. Swift M, Morrel D, Massey RB, Chase CL. Incidence of cancer in 161 families affected by ataxia-telangiectasia. N Engl J Med. 1991; 325(26):1831-6.

36. Athma P, Rappaport R, Swift M. Molecular genotyping shows that ataxiatelangiectasia heterozygotes are predisposed to breast cancer. Cancer Genet Cytogenet. 1996; 92(2):130-4.

37. Janin N, Andrieu N, Ossian K, Laugé A, Croquette MF, Griscelli C, et al. Breast cancer risk in ataxia telangiectasia (AT) heterozygotes: haplotype study in French AT families. Br J Cancer. 1999; 80(7):1042-5.

38. Swift M, Chase C. Cancer and cardiac deaths in obligatory ataxiatelangiectasia heterozygotes. Lancet. 1983; 1(8332):1049-50.

39. Harbort CJ, Soeiro-Pereira PV, von Bernuth H, Kaindl AM, Costa-Carvalho BT, Condino-Neto A, et al. Neutrophil oxidative burst activates ATM to regulate cytokine production and apoptosis. Blood. 2015; 126(26):2842-51.

40. Ko DT, Alter DA, Guo H, Koh M, Lau G, Austin PC, et al. High-density lipoprotein cholesterol and cause-specific mortality in individuals without previous cardiovascular conditions: the CANHEART Study. J Am Coll Cardiol. 2016; 68(19):2073-83

41. Rosenson RS, Brewer HB Jr, Ansell BJ, Barter P, Chapman MJ, Heinecke JW, et al. Dysfunctional HDL and atherosclerotic cardiovascular disease. Nat Rev Cardiol. 2016; 13(1):48-60.

42. Andrade IG, Costa-Carvalho BT, Silva R, Hix S, Kochi C, Suano-Souza FI, et al. Risk of atherosclerosis in patients with ataxia telangiectasia. Ann Nutr Metab. 2015; 66(4):196-201 